\title{
13. VEIN STRUCTURES AND THEIR TECTONIC IMPLICATIONS FOR THE DEVELOPMENT OF THE IZU-BONIN FOREARC, LEG $126^{1}$
}

\author{
Y. Ogawa, ${ }^{2}$ J. Ashi, ${ }^{3}$ and K. Fujioka ${ }^{3,4}$
}

\begin{abstract}
Samples with vein structures were taken from Sites 787 and 793 in the forearc basin of the Izu-Bonin island arc off Aoga Shima and Sumisu Jima, respectively, between the present volcanic front and the outer arc high. The samples were studied by thin section, X-ray radiograph, and magnetometer; they are discussed with respect to the tectonic implication of the vein structures to the island-arc development.

Vein structures are developed in finer, more clayey, preferentially radiolarian-bearing mudstone, subvertical to the bedding plane, which is mostly horizontal. The veins are restricted to certain horizons: in the upper Oligocene at Site 787 and in the lower Miocene at Site 793. The veins are filled with a dominant clay mineral (montmorillonite), which flowed into the vein when the fracture and concomitant stress drop occurred. Some clay mineral was deposited from the fluid that invaded the vein. Some veins might have occurred as hydraulic fractures. The shape, mode of occurrence, and other structural features indicate that the veins originated either as extension fractures or shear cleavages, and then were rotated by the following shearing parallel to the bedding. Sometimes the bedding-parallel slip planes are dislocated by the veins, and sometimes vice versa. This suggests that the vein formation and bedding parallel slip alternately occurred within the same stress environment.

Vein attitude was measured by a magnetometer, after alternating field demagnetization; we interpret that they originally formed as subvertical planes, the trends of which average to $\mathrm{N} 45 \mathrm{~W}$. The quantity of samples studied was small, but the trends suggest that the stress field for veining might have had a relative extensional stress axis that lay subhorizontally and trended generally northeast. This stress orientation might be attributed to either bending or normal faulting in the forearc basin, at a time when the arc trended northwest.
\end{abstract}

\section{INTRODUCTION}

"Vein structure" is sporadically seen in compacted mudstones as an array of mud veins (Ogawa, 1980; Cowan, 1982; Ogawa and Miyata, 1985; Helm and Vollbrecht, 1985; Knipe, 1986; Lundberg and Moore, 1986; Brown and Behrmann, 1990). Each mud vein is $100 \mu \mathrm{m}$ to $1 \mathrm{~mm}$ in width and $1 \mathrm{~cm}$ in length in cross section, but they continue considerably longer in the third dimension. Veins are closely spaced at $1-\mathrm{mm}$ intervals to make a specific structure in an array. Some veins often show a sigmoidal shape (Cowan, 1982) but not always. There are many variations of the shape of each vein and sets of veins, and they are classified in several ways, as in figure 3 of Ogawa and Miyata (1985). The basic type of vein, however, is a fish style.

This structure has long been recognized on land in central Japan, but only recently has it been described in detail by Ogawa (1980) from the Miura-Boso peninsulas, central Honshu, which corresponds to the northern extension of the Izu-Bonin forearc. Many examples have been cited by Deep Sea Drilling Project (DSDP) drilling in the area, particularly on Legs 57 and 87 in the Japan Trench landward slope (Arthur et al., 1980; Leggett et al., 1987), and on Legs 67 and 84 in the Middle America Trench landward slope off Guatemala (Cowan, 1982; Ogawa and Miyata, 1985). Most of those examples are known from the trench-landward slopes of nonaccretion-type convergent margins, that is, the veins favor the trench-slope covers. Beside these examples, some cases have been found in backarc settings or in

\footnotetext{
' Taylor, B., Fujioka, K., et al., 1992. Proc. ODP, Sci. Results, 126: College Station, TX (Ocean Drilling Program).

${ }^{2}$ Department of Earth and Planetary Sciences, Kyushu University, 33 Hakozaki, Fukuoka 812, Japan.

${ }^{3}$ Ocean Research Institute, University of Tokyo, 1-15-1 Minamidai, Nakano, Tokyo 164, Japan.

${ }^{4}$ Present address: Japan Marine Science and Technology Center, 2-14 Natsushima, Yokosuka, Kanagowa 238, Japan.
}

accretionary prisms, all of which are involved within a horizontal stretching regime, as will be discussed later.

The examples described and discussed in this paper were taken from the forearc setting of the Izu-Bonin (Ogasawara) Arc during drilling at Ocean Drilling Program (ODP) Sites 787 and 793 (Fig. 1). Other sites, such as $788,789,790,791$, and 792 , did not yield any vein structures. Site 784 , just on the foot of the serpentine diapir mound on the more trenchward slope of the Izu-Bonin Arc, has examples of vein structures within Pleistocene and Miocene sections (Shipboard Scientific Party, 1990). However, the vein horizons tend to be restricted to mostly Oligocene to Miocene levels. The restricted sites and horizons may be a result of tectonic settings and lithologies that depend largely upon age; although the critical horizons differ between Sites 787 and 793, the latter contains more radiolarians. In these cases, the critical lithologies seem to be either radiolarian or vitric claystone or mudstone, or just claystone. No coarse sediments, such as sandstone or coarse tuffaceous rocks, have any vein structures.

Our examples, therefore, have definite sedimentary and tectonic significance for the development of the Izu-Bonin island arc. To determine this significance, we must first describe their occurrence and note the vein attitude using a magnetometer; we will then discuss the origin and related tectonic implication of the vein structures in the context of island-arc development.

\section{METHODS}

Samples were taken with a $25-\mathrm{cm}^{3}$ plastic tube onboard the JOIDES Resolution. Arrows indicate the vertical upward direction. The X, Y, and $\mathrm{Z}$ abscissa were set as in Figure 2. X-ray radiographs of thinned slices of the core samples on an $\mathrm{X}-\mathrm{Z}$ plane and ordinary pictures were taken onshore (Fig. 3). Thin sections were made of the same position for X-ray radiographs. Some of the samples were so soft from desiccation that treatments of any kind could not be undertaken. The samples were then treated with a magnetometer to determine the original attitude of the veins according to the methods described below. 
A

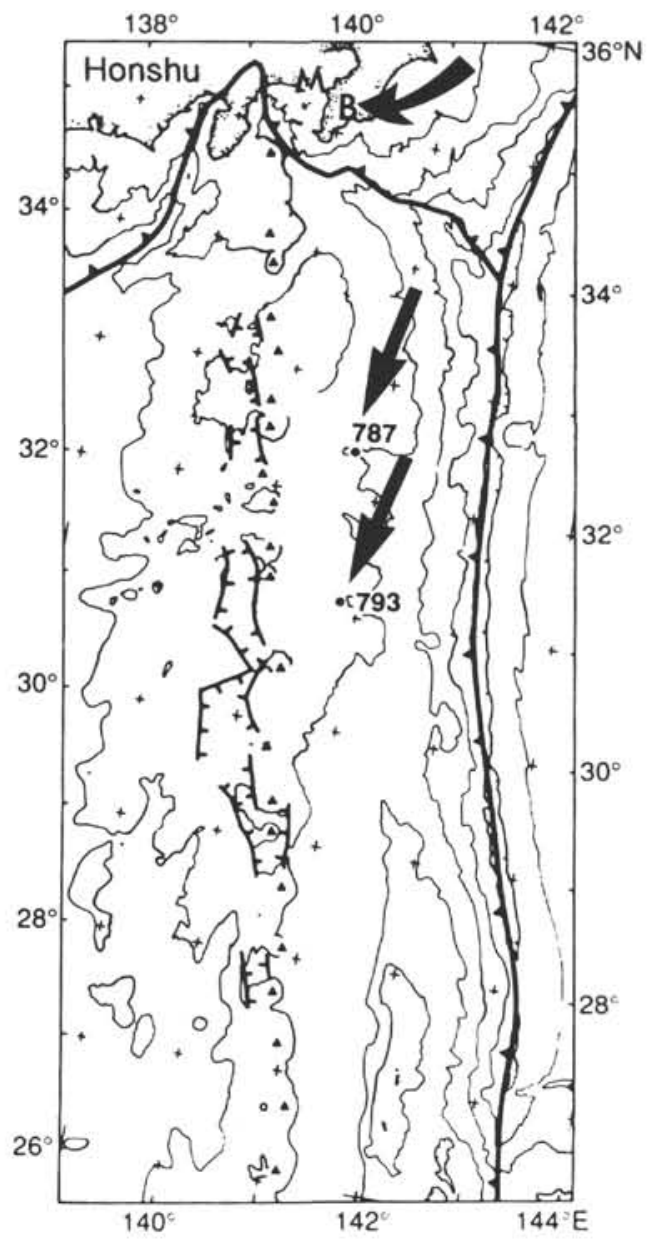

B

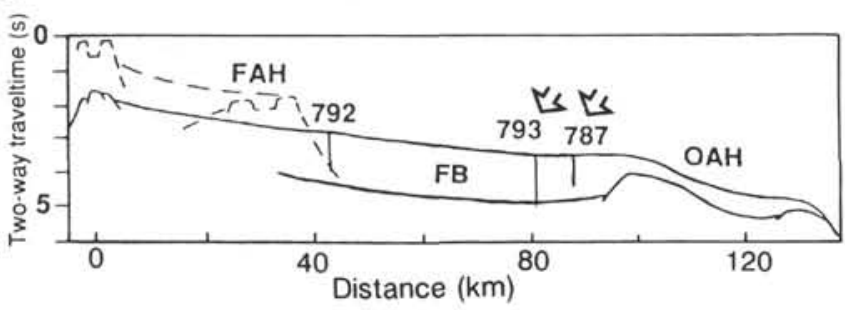

Figure 1. A. Index map for sample location. Topmost arrow shows the Miura (M) and Boso (B) peninsulas, central Honshu. B. Schematic section of the IzuBonin Arc with locations of Sites 787, 792, and 793. OAH = outer-arc high, $\mathrm{FB}=$ forearc basin, and $\mathrm{FAH}=$ forearc high.

\section{DESCRIPTION OF THE VEIN STRUCTURES \\ General Description}

Site 787

Site 787 is located at $112 \mathrm{~km}$ outward from the volcanic front, Aoga Shima (Aogashima Island), and inward of the outer-arc high (Figs. 1 and 4). According to the seismic section (Taylor, Fujioka, et

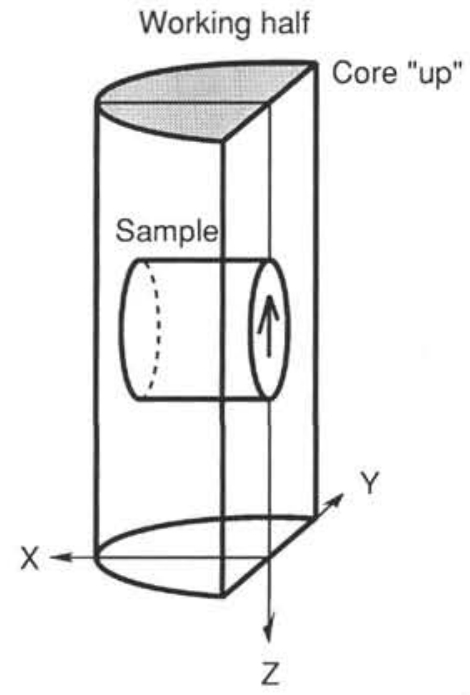

Figure 2. Sample direction ( $\mathrm{X}$ and $\mathrm{Y}$ ) and abscissa $(\mathrm{Z})$ in the working half of core.

al., 1990, pp. 407-413), the surface of the forearc basin dips seaward at $1.6^{\circ}$. The Oligocene to Holocene strata and the Miocene and Pliocene unconformities abut toward the east upon the Eocene outerarc high. Strata are normally faulted through the upper section, suggesting that horizontal west-east stretching has occurred rather recently. Thus, the present forearc is known as a failed rift, which was formed for a short period during the early Oligocene (Taylor, Fujioka, et al., 1990, pp. 66-96).

The site was drilled to about $320 \mathrm{~m}$ below the seafloor (mbsf) to the upper Oligocene. Only very thin Miocene and Pliocene sections were recovered, probably because of erosion in the old canyon. The Oligocene strata are normally faulted. Most of the samples that show vein structures are radiolarian-bearing, tuffaceous mudstone or claystone, but they are not as radiolarian-dominant as the samples from Site 793 described below.

Sample 126-787B-9R-1, 11-13 cm, has spaced thin veins of a braided type within bioturbated mudstone. Bedding is horizontal, and veins are almost vertical (Fig. 3B-1). The veins cut and dislocate the trace fossils, suggesting a small displacement in a normal fault sense. Sample 126-787B-11R-3, 21-23 cm, has a braided type of vein in reddish mudstone (Fig. 3A-2). In this case, the general trend of the vein is steep to the bedding, which is horizontal. Sample 126-787B$21 \mathrm{R}-3,37-38 \mathrm{~cm}$, has and irregular, but braided vein type with a clastic dyke (Fig. 3A-3). These three examples are all from the upper Oligocene strata. The development of the veins is not so remarkable at Site 787; they are more or less irregular and scarce.

\section{Site 793}

Site 793 is located at about $58 \mathrm{~km}$ outward from the volcanic front, east-southeast of Sumisu Jima (Sumisu Island) (Figs. 1 and 4). In the north-south seismic section, the strata are almost horizontal, but in the west-east section the surface of the slope dips seaward at about $0.72^{\circ}$. The strata are associated with scarce undulations and small scale displacement normal faults (Taylor, Fujioka, et al., 1990, pp. 407-413).

A 172-m-thick middle and lower Miocene unit was drilled after drilling without coring from 100 to 580 mbsf. Below this, a 645-mthick upper and lower Oligocene sequence was drilled above the lower Oligocene andesitic pyroclastic and lava rocks. Most of the Oligocene sections are volcaniclastic rock, whereas the Miocene section is less tuffaceous and muddy or rather clayey. Mud vein structures were observed only in the Miocene sections, particularly in the silty claystone, commonly in radiolarian-rich claystone from 
A

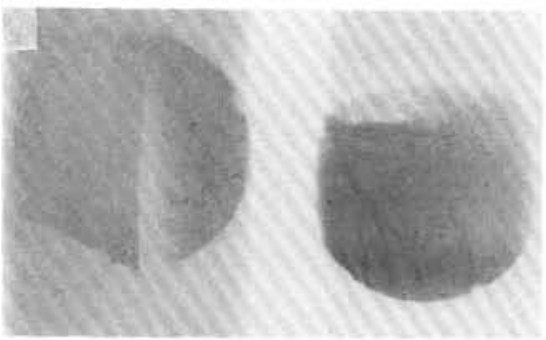

1
2

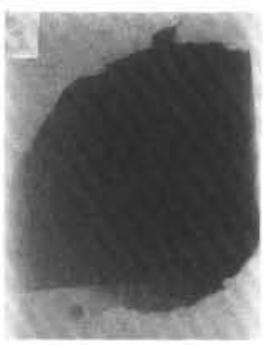

3

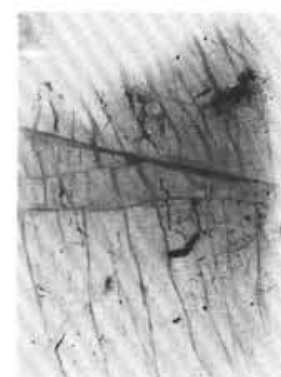

9

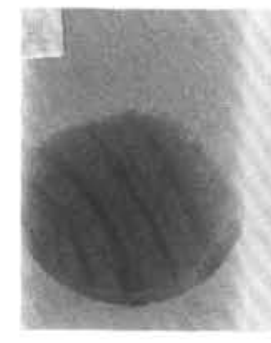

4

B

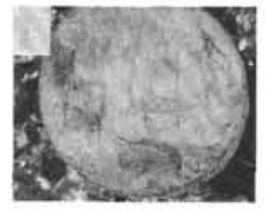

1

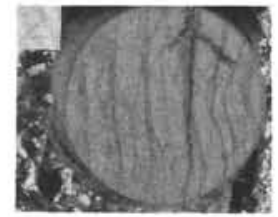

2

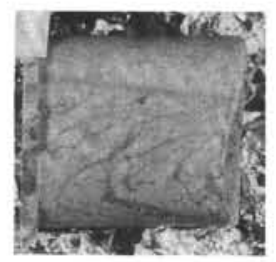

7

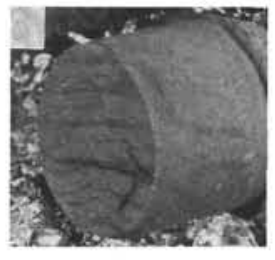

3

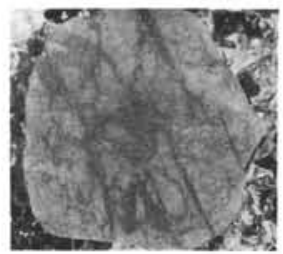

8
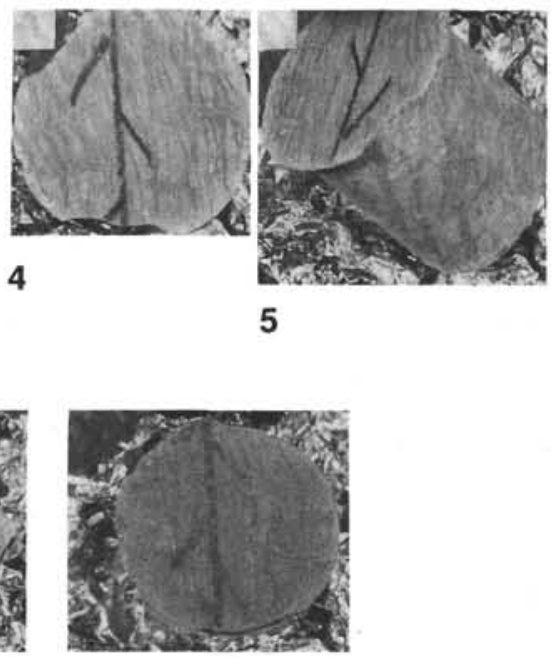

9

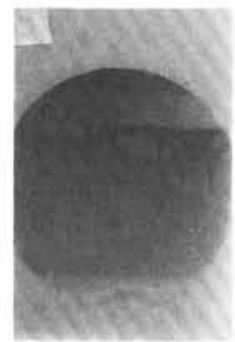

8

$2 \mathrm{~cm}$

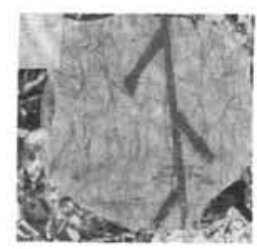

6

Figure 3. A. X-ray radiographs. (1) Sample 126-787B-9R-1, 11-13 cm. (2) Sample 126-787B-11R-3, 21-23 cm. (3) Sample 126-787B-21-3, 37-39 cm. (4) Sample 126-793B-12R-1, 21-23 cm. (5) Sample 126-793B-16R-5, 94-96 cm. (6) Sample 126-793B17R-2, 73-75 cm. (7) Sample 126-793B-18R-3, 82-84 cm. (8) Sample 126-793B-19R-4, 25-27 cm. (9) Reference sample from the Miura Group, Chiyogasaki, Miura peninsula, Honshu. B. Sample photographs. (1) Sample 126-787B-9R-1, 11-13 cm. (2,3) Sample 126-793B-12R-1, 21-23 cm. (4, 5) Sample 126-793B-16R-5, 94-96 cm. (6, 7) Sample 126-793B-17R-2, 73-75 cm. (8) Sample 126-793B-18R-3, 82-84 cm. (9) Sample 126-793B-19R-2, 25-27 cm. 


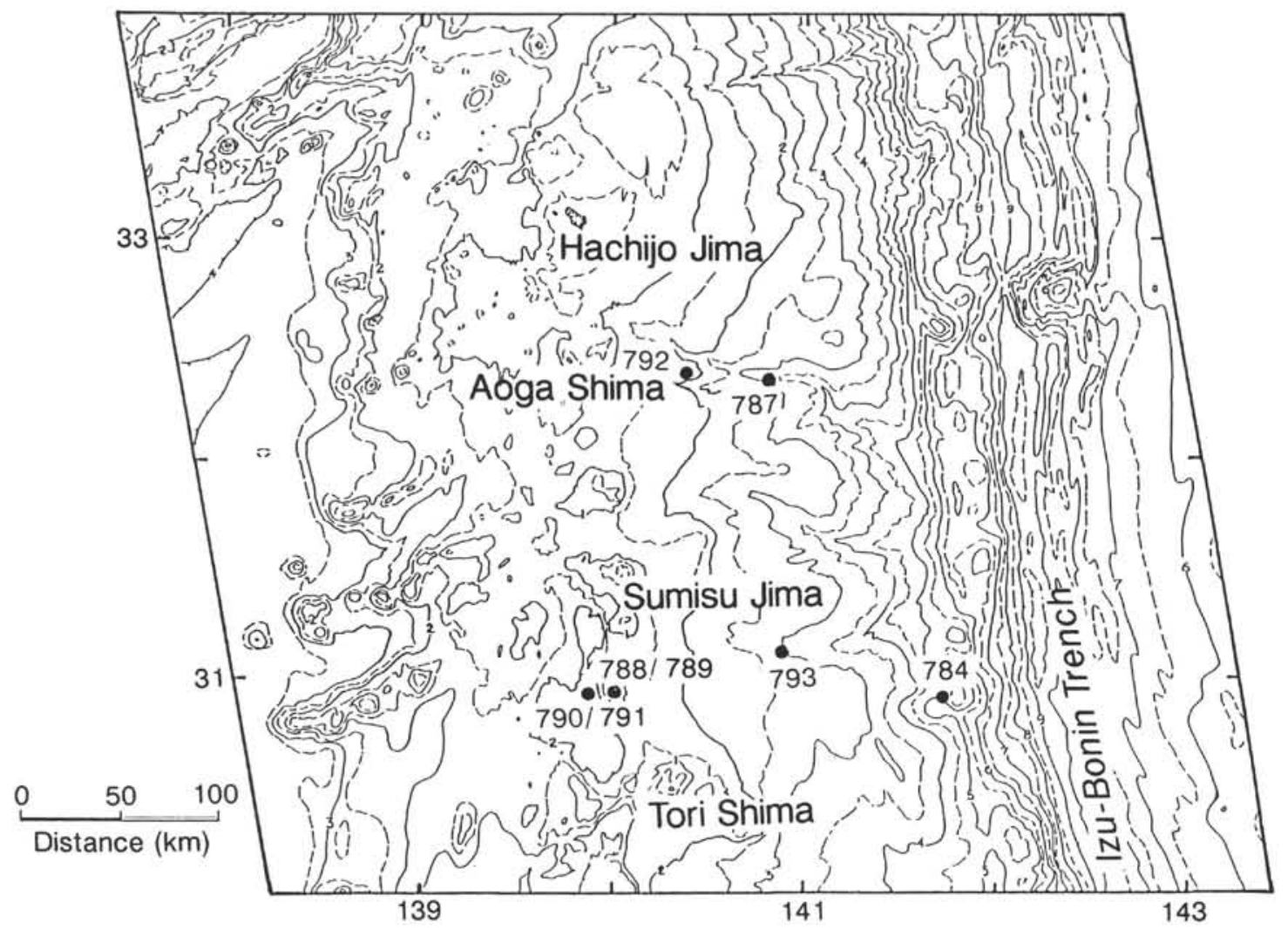

Figure 4. Detailed bathymetric map (modified after Taylor et al., 1990) around the sample sites, including Site 784 of Leg 125. Courtesy of A. Nishimura.

Cores 126-793B-12R to -30R. Vein structures were not observed in the Oligocene section, which is dominant in volcaniclastic materials. In the Oligocene section clastic dikes, mineral veins of zeolite, and/or calcite were seen instead.

Sample 126-793B-12R-1, 21-23 cm, has sigmoidal veins with a fair amount of braiding in bluish mudstone (Figs. 3A-4, 3B-2, and 3B-3). The oblique view of the sample (Fig. 3B-3) indicates that the veins dip vertically. The veins are bold at their central part and thinned and braided toward the edges, which are branched. The sigmoidal pattern seems to be caused by the drag sliding along the bedding plane, although no sharp slip planes were recognized. Sample 126-793B$16 \mathrm{R}-5,94-96 \mathrm{~cm}$, has very closely spaced and braided, anastomosed, and sigmoidal veins in reddish claystone (Figs. 3B-4 and 3B-5). Although braided, the general dip of the veins is vertical. Veins cut and dislocate the horizontal trace fossils in an antithetic fashion by normal faulting. Sample 126-793B-17R-2, 73-75 cm, has thin and anastomosed veins within a pinkish claystone (Figs. 3A-6, 3B-6, and 3B-7). A thick, dark fault zone of 2-mm width truncates the vein structures. The general dip of the veins is also vertical in this case. Sample 126-793B-18R-3, $82-84 \mathrm{~cm}$, has very irregular but anastomosing veins, dipping about $72^{\circ}$ in a bluish mudstone (Figs. 3A-7 and 3B-8). Sample 126-793B-19R-2, 25-27 cm, has sigmoidal veins in a bluish mudstone of about $80^{\circ}$ dip (Fig. 3B-9).

Beside these vein structures, several examples of small-scale normal faults were described within the Miocene section (Taylor, Fujioka, et al., 1990, pp. 315-403).

\section{Thin Sections and SEM Descriptions}

Thin sections and samples for the scanning electron microscope (SEM) were prepared for most rocks that had vein structures (Figs. 5, 6, 7,8 , and 9), although some were not successful because of the extremely soft conditions of the samples. In general, the vein parts are dark in color; however, the dark vein parts become rather light when the samples are dried, so that the darkness may be caused by a higher water content. The vein part is exclusively of a higher X-ray absorption (Fig. 3A), which may be caused by the more compacted or recrystallized character within the vein.

\section{Site 787}

Vein-structure-bearing samples at Site 787 are more or less scarce in radiolarians, but some parts still have their tests within the clay matrix. Some tuffaceous fragments, such as plagioclase, pyroxenes, and so on, were seen. Each vein is anastomosed and has sharp boundaries between the matrix (Fig. 5). Fragments of radiolarians or ash can been seen on the boundaries between the veins and matrix.

The surfaces of the vein structure were observed by SEM from the matrix side. Small-scale lineations may indicate a slickenside structure, suggesting scratches and displacement along the vein surfaces (Fig. 6). Some veins are displaced in a normal fault sense, as in Figure 3. This is coincident with the small-scale normal fault cutting the bioturbation.

\section{Site 793}

Vein-structure-bearing samples at Site 793 are considerably radiolarian dominant, as shown in Figures 7 and 8 . Radiolarian content can be as much as $40 \%$ in volume. In this case, the veins are also anastomosed and make sharp contact with the matrix. In the case of Figure 8 , a scarplike topography is seen on the boundary. Tests and fragments of radiolarians and ash are associated either within the veins or on the border of the veins, but the latter case is more common. The vein part is more clayey than in the matrix, which is much richer in radiolarian tests and fragments (Figs. 7 and 8). Sometimes thin 
A

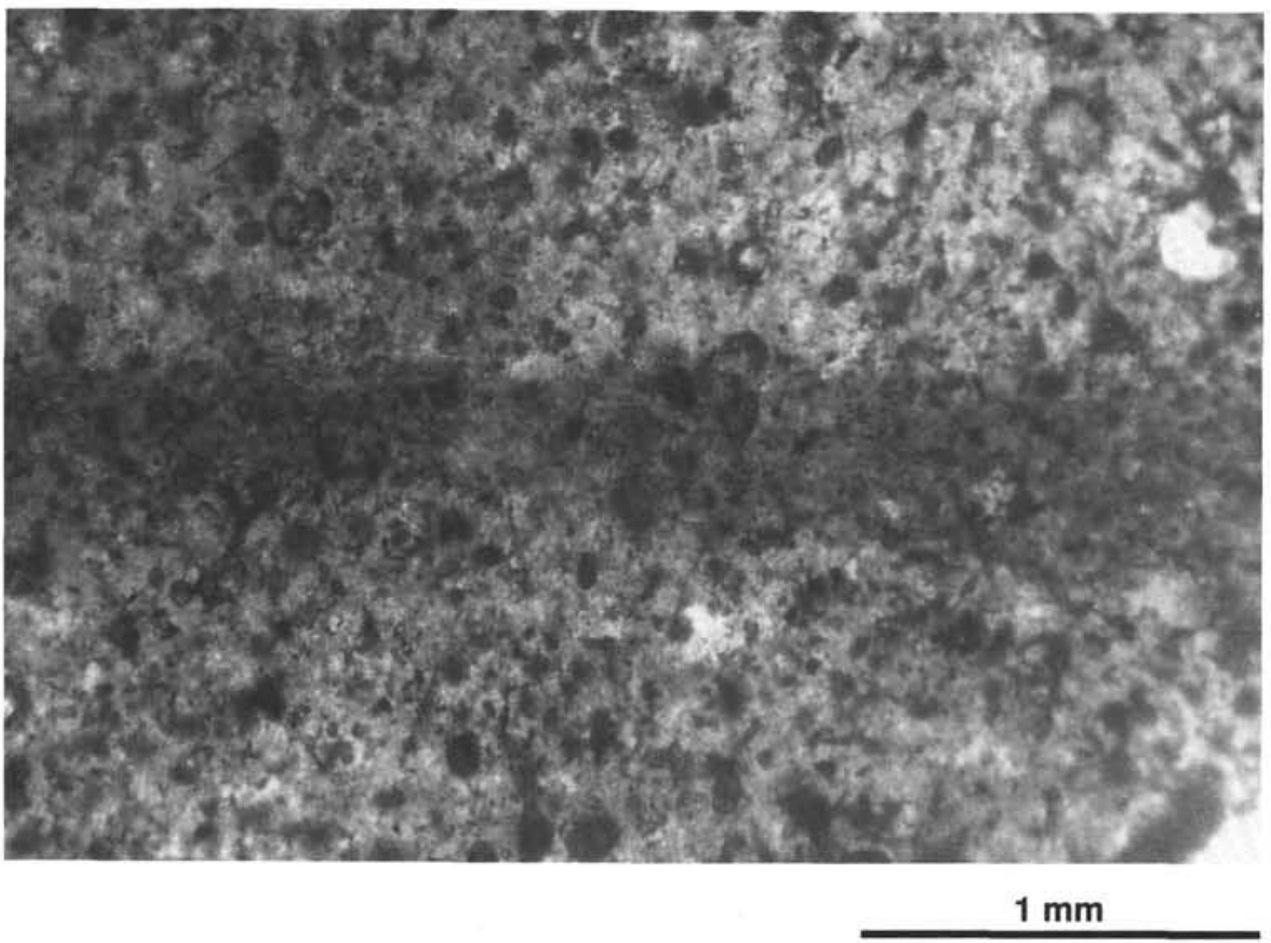

B

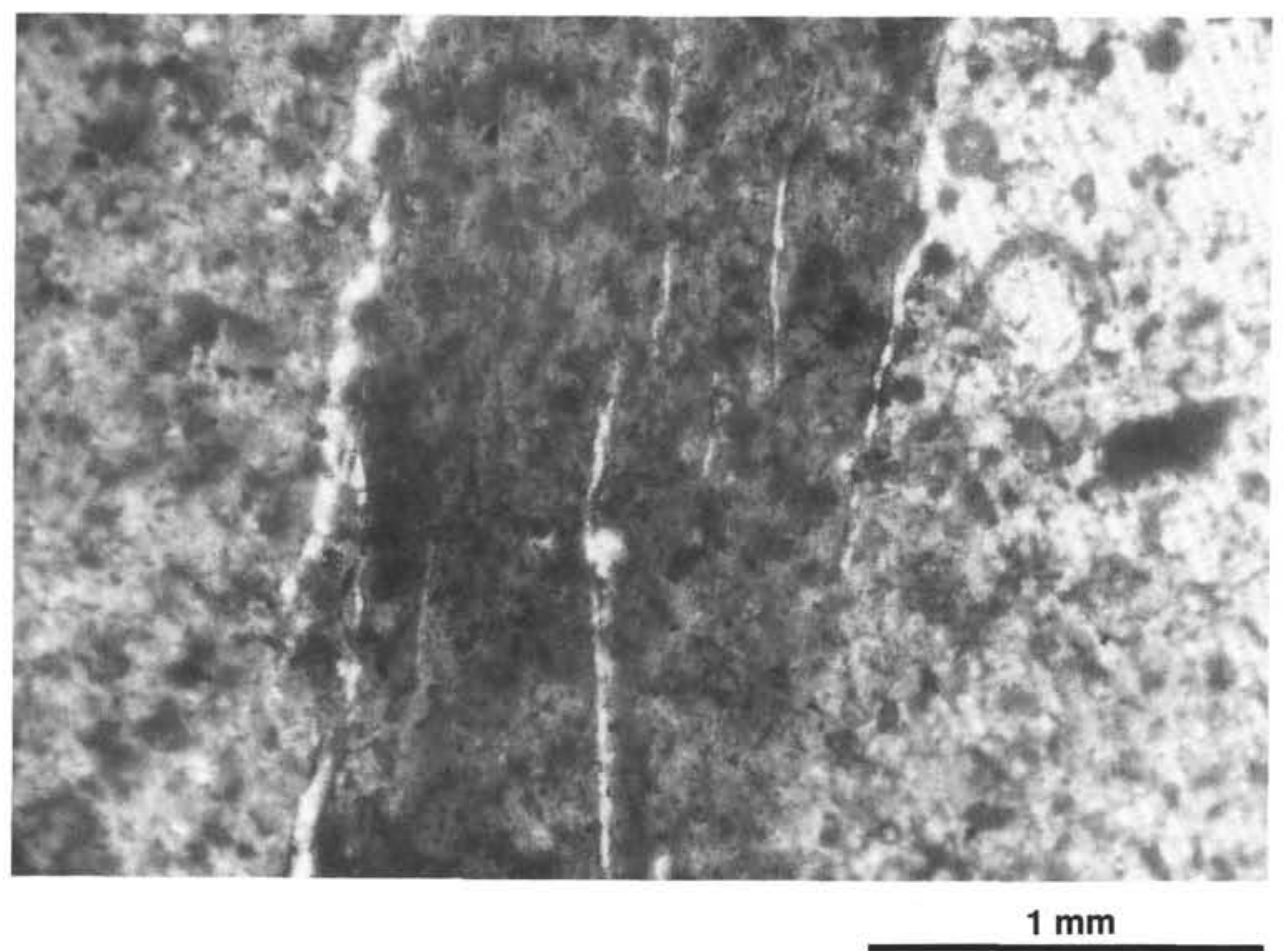

Figure 5. A, B. Photomicrographs of vein structures (Sample 126-787B-10R-1, 11-13 cm, open nicols), indicating that the vein in thin section is usually darker than the matrix (see exception in Fig. 9), and the vein wall is sharp. 


\section{A}

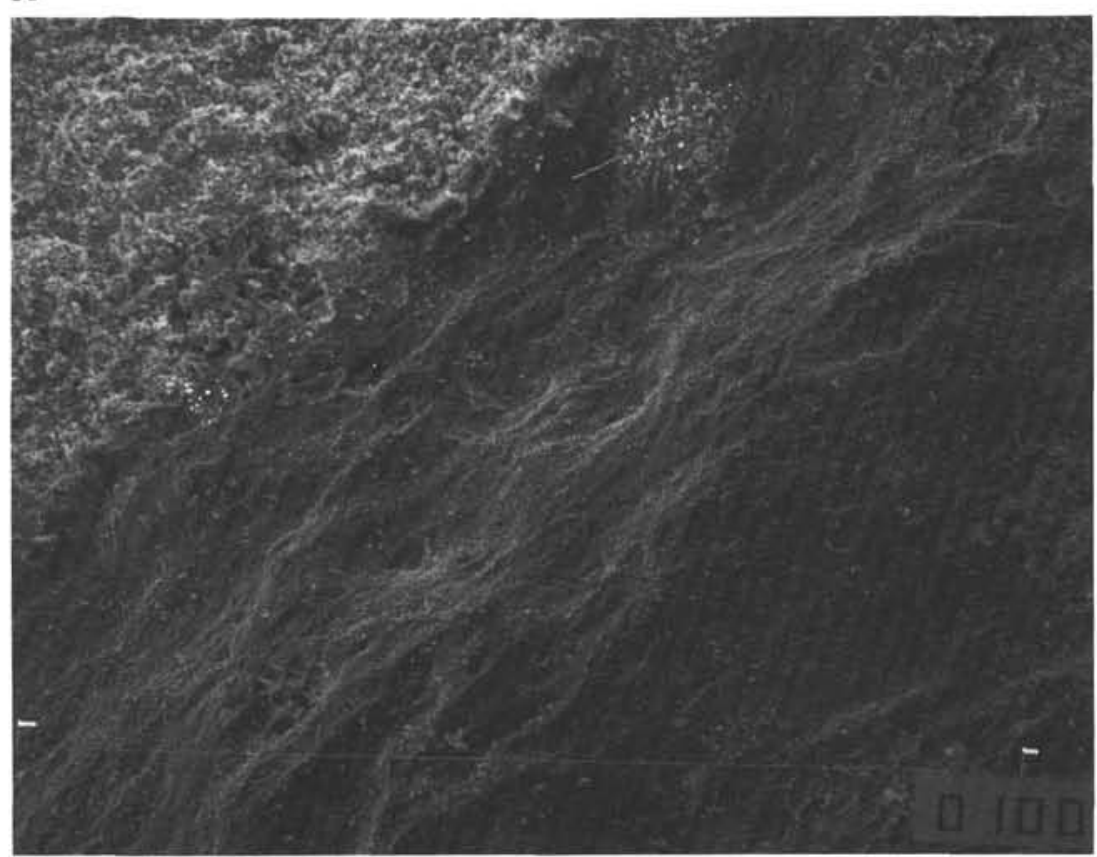

$2 \mathrm{~mm}$

B

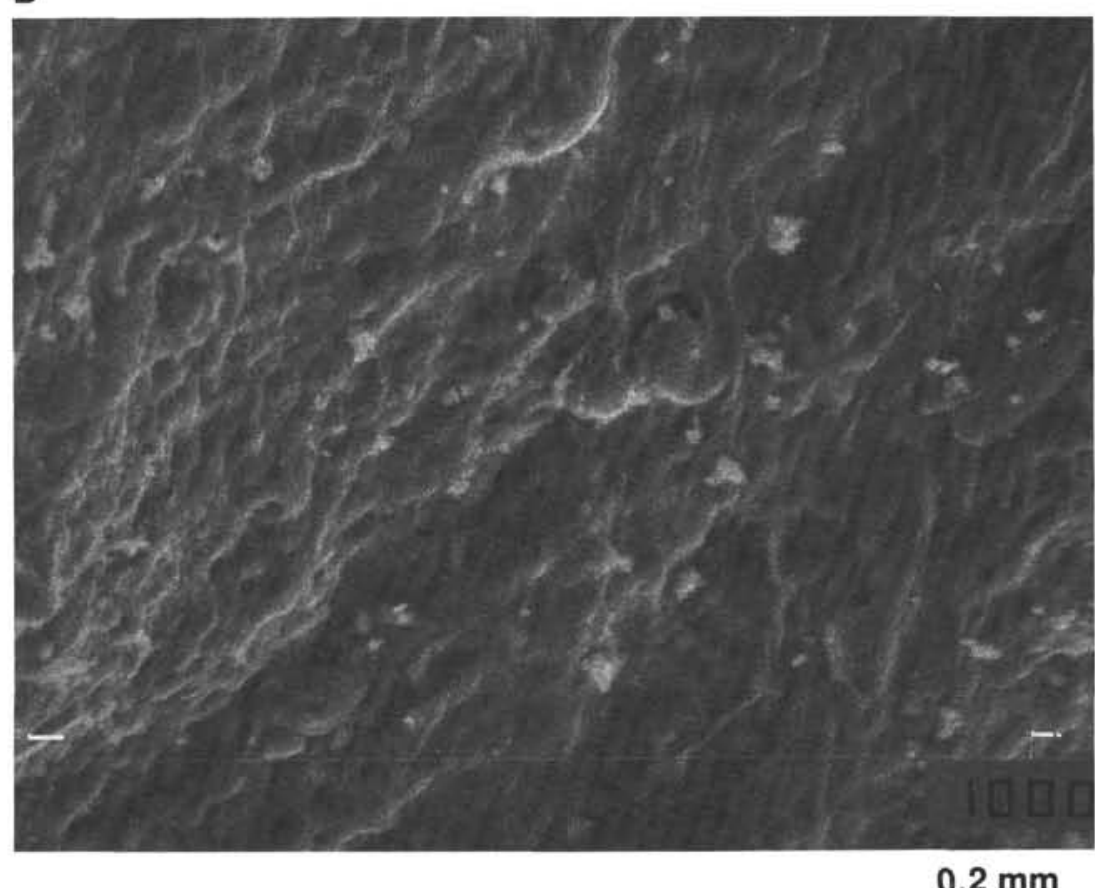

Figure 6. A. Scanning electron microscope (SEM) photograph of vein part, looking at the vein surface (Sample 126-787B-8R-1,11-13 cm), indicating the slip surface. B. Enlargement of Figure 6A.

(about several tens of microns thick) layers of transparent clay zones are on both outermost sides of the veins (Fig. 7).

From these SEM studies and photomicrographs, it is known that the vein part is much richer in clay than the matrix, which includes some fragments. In these cases, clay minerals are sometimes arranged parallel to the walls of the vein (Fig. 9B).

Thus, we conclude that the veins were preferentially formed in more radiolarian-dominant claystone or mudstone, and the vein part was occupied by clay minerals arranged parallel to the extension of the vein. These observations suggest that clay minerals were deposited either by clay mineral injection or recrystallization within the veins.

\section{Vein Shape and Arrangement}

Veins were generally formed parallel to each other, and the most primitive style in the incipient stage is a fish style (Fig. 10). However, 


\section{A}

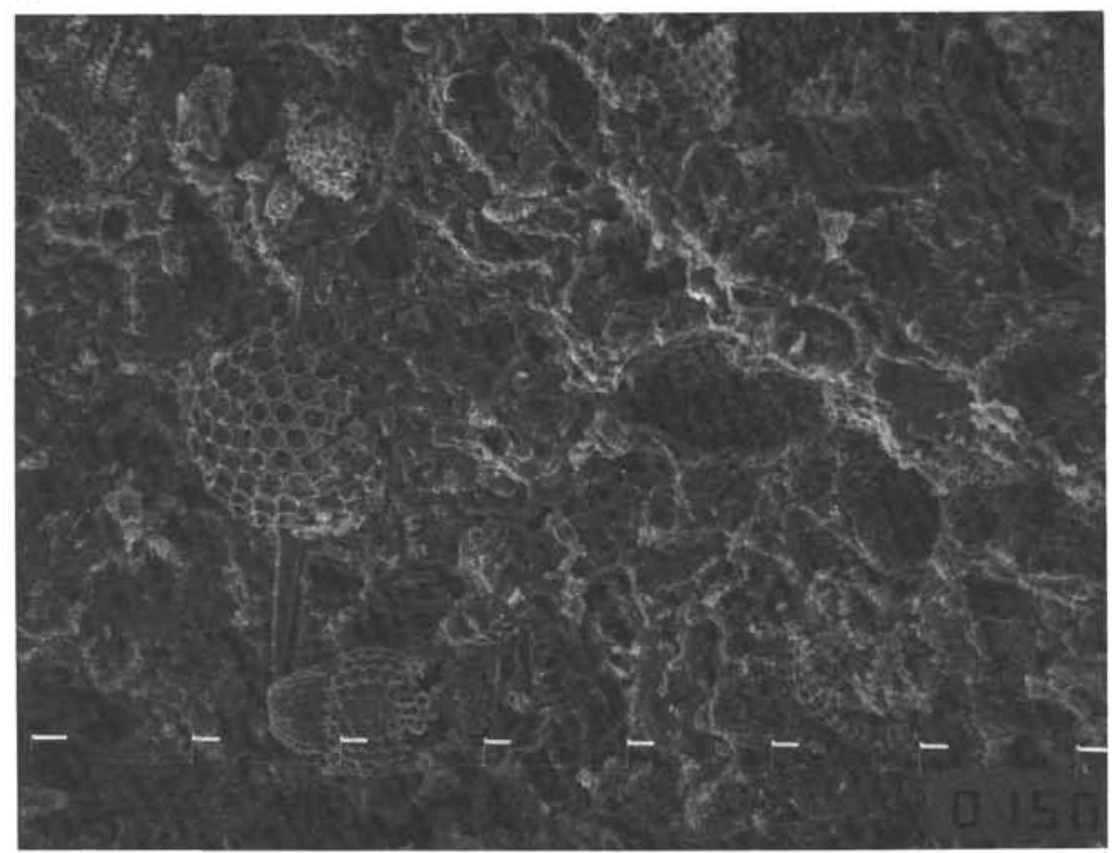

$0.2 \mathrm{~mm}$

\section{B}

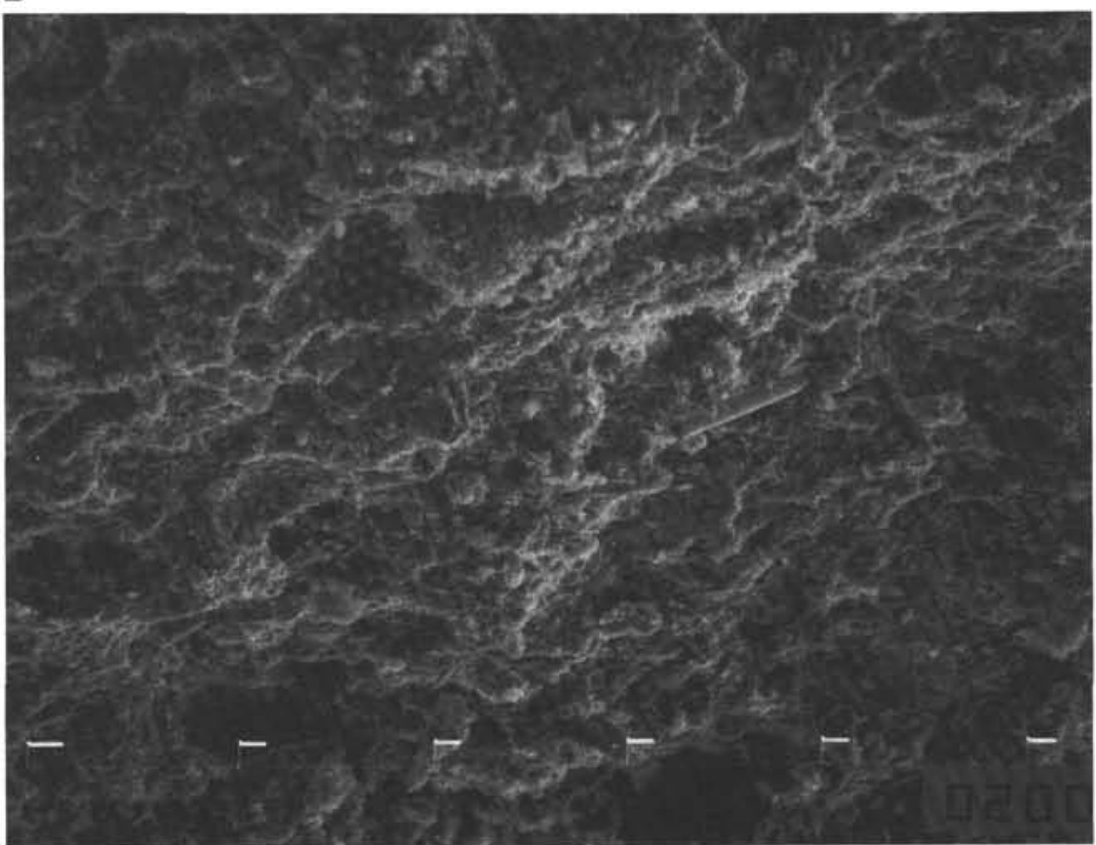

$0.2 \mathrm{~mm}$

Figure 7. A. SEM photograph of nonvein part illustrating radiolarian-dominant mudstone (Sample 126793B-12R-1, 21-23 cm). B. Vein part illustrating parallel arrangement of clay minerals and spine (same sample as in Figure 7A).

in many cases the vein develop in an anastomosing manner. The anastomosing angles are mostly $10^{\circ}$ to $20^{\circ}$ (Fig. 9A). We usually did not see displacements along the vein of the incipient stage, suggesting that the vein is just an extensional fracture, particularly in the central part. Sometimes, however, veins displace the bedding trace or previous veins, indicating shear fractures. In the latter case, there are two types of shear fracture.
In one type, bifurcation occurs at both ends (the top and bottom of the vein), even in fish-style veins (Fig. 10; see fig. 3 in Ogawa and Miyata, 1985). The bifurcation may represent conjugate shear fractures. In the other case, the veins have two or more stages. Clear-cut relations between the first and second stages are few, but it is always suggested that the central bolder part is older than the thin parts, which are seen as braiding from the central part that occurred in the second 


\section{A}

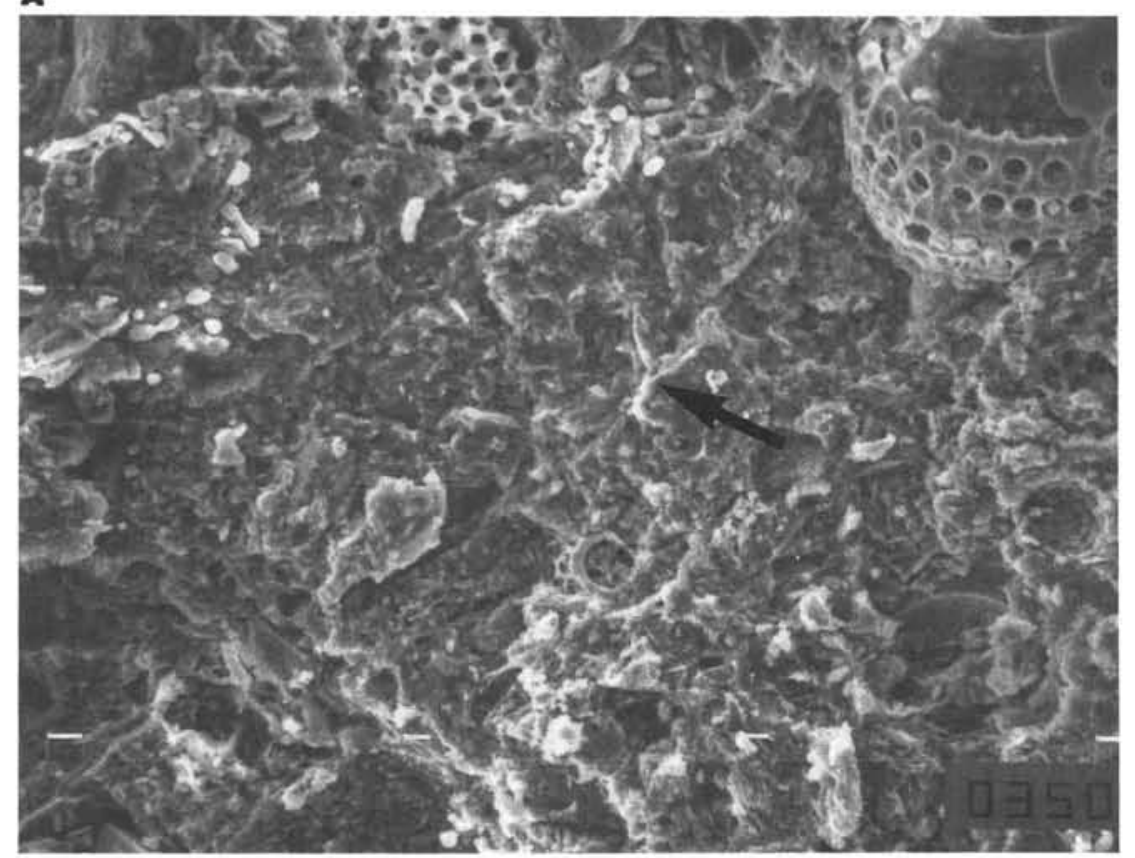

$0.1 \mathrm{~mm}$

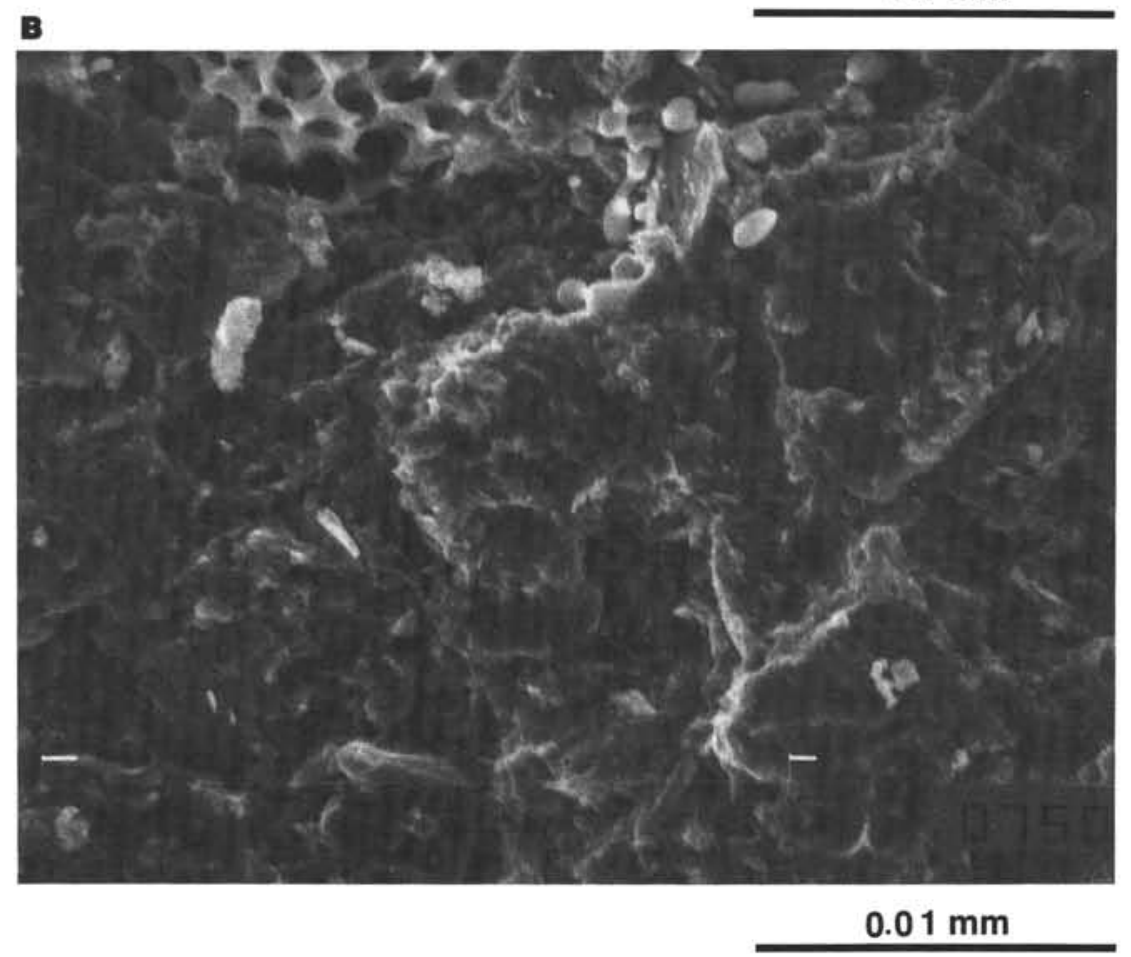

Figure 8. A, B. SEM photographs of vein part (Sample 126-787B-8R-1, 11-13 cm). The arrow in Figure 8A indicates the wall of the vein enlarged in Figure 8B.

stage (Fig. 10; Knipe, 1986). In most cases, veins of the second stage are more vertical than in the first stage, which has rotated around the central part, opposing the previously mentioned vein obliqueness to the bedding, unlike the examples of Knipe (1986) or Saito and Nagahama (1989).

Sometimes, a bedding subparallel fault gouge was observed, as explained by Kimura et al. (1989). The feature inside of the fault is very similar to that of the vein structure, but the former never thins out and is almost parallel to the bedding plane and is straighter. The fault gouge has a cataclastic texture, as indicated in Ogawa and Miyata (1985), suggesting that a rather strong breaking of the grains occurred by strain hardening. Sometimes veins cut the fault gouge and sometimes vice versa, indicating that the vein formed both before and after the bedding plane sliding. 
A

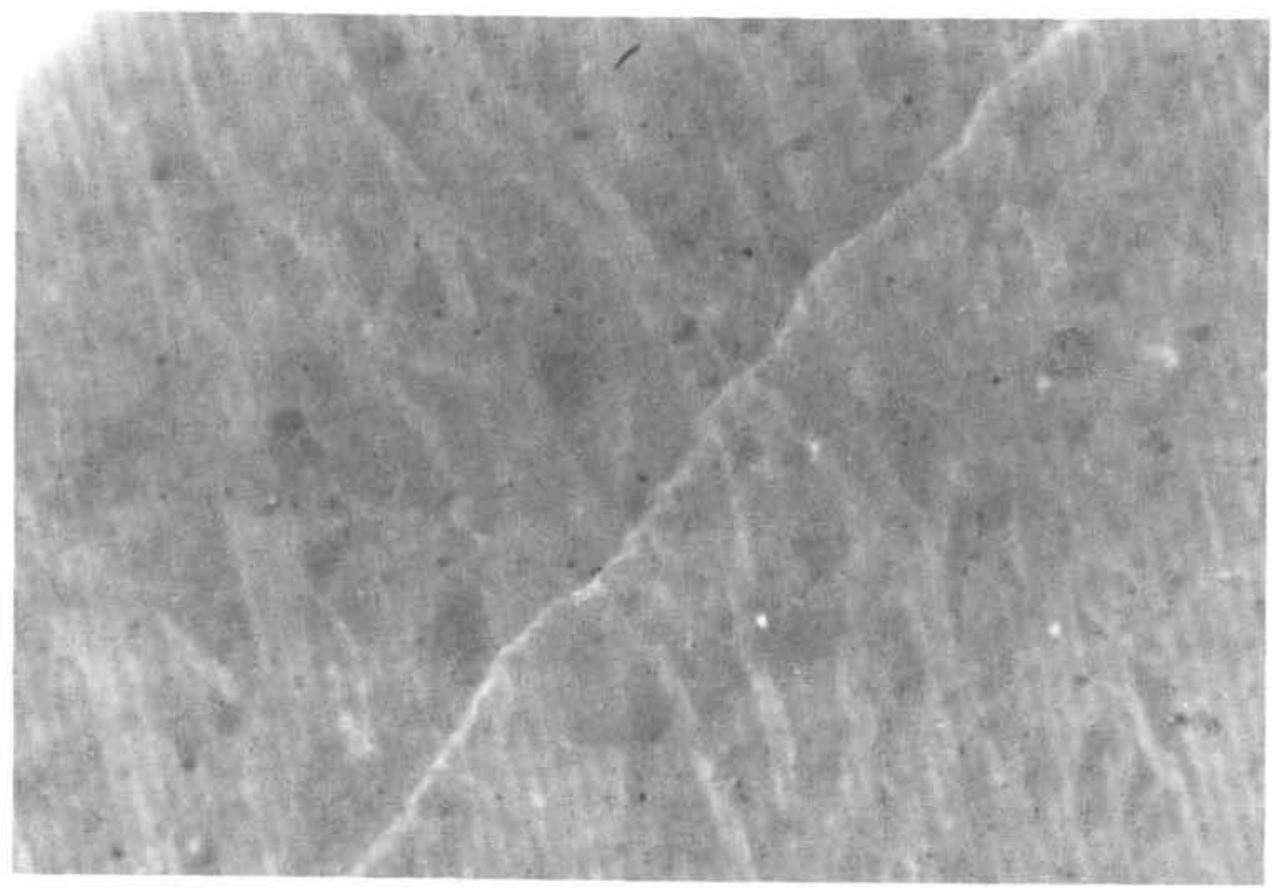

$1 \mathrm{~mm}$

\section{B}

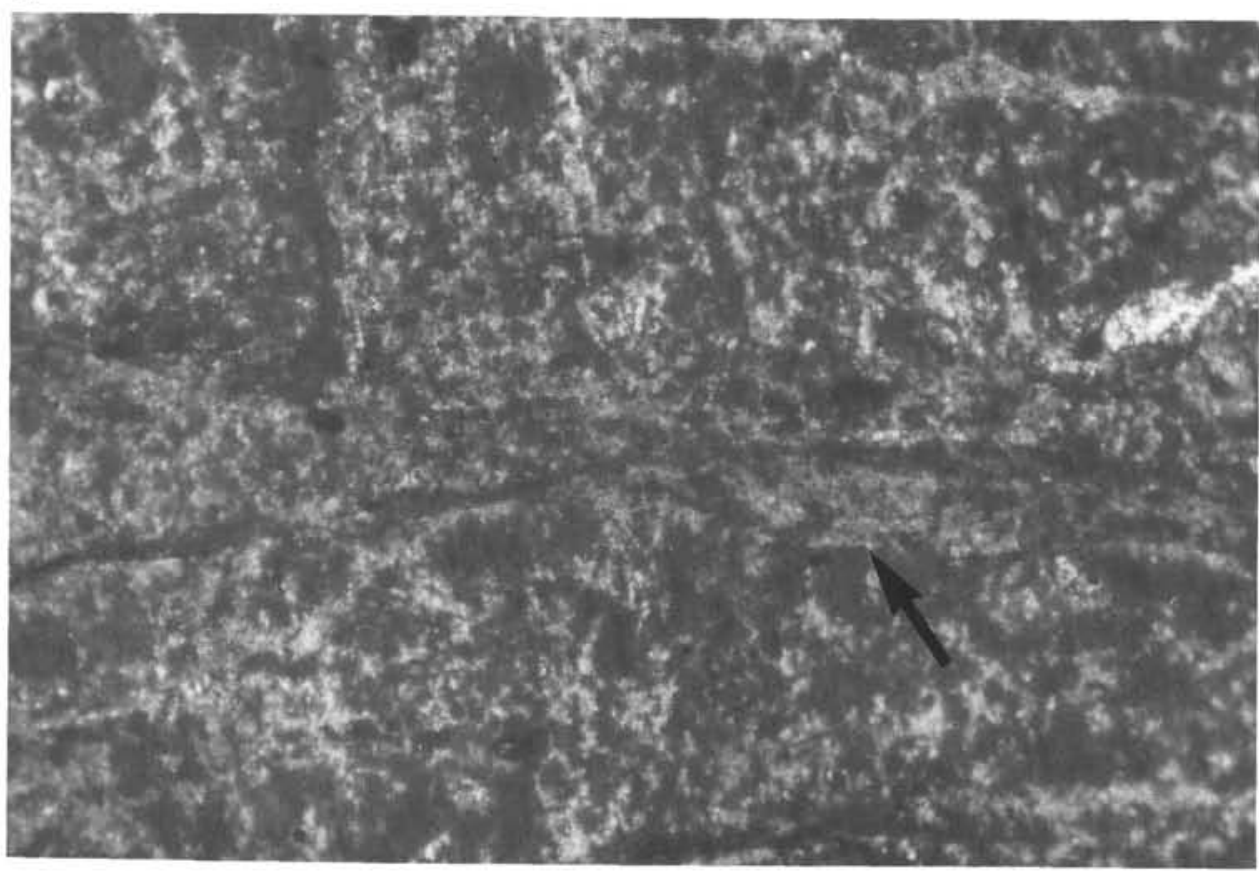

$1 \mathrm{~mm}$

Figure 9. Photomicrographs of thin sections of veins. A. Sample 126-793B-16R-5, 94-96 cm (open nicols), indicating braided, sigmoidal, and inner part of clay-rich vein; in this case, the vein part is brighter. B. Sample 126-793B-19R-2, $25-27 \mathrm{~cm}$ (crossed nicols), indicating clay arrangement parallel to the vein inside, shown with an arrow. The vein is horizontal in Figure 9B. 

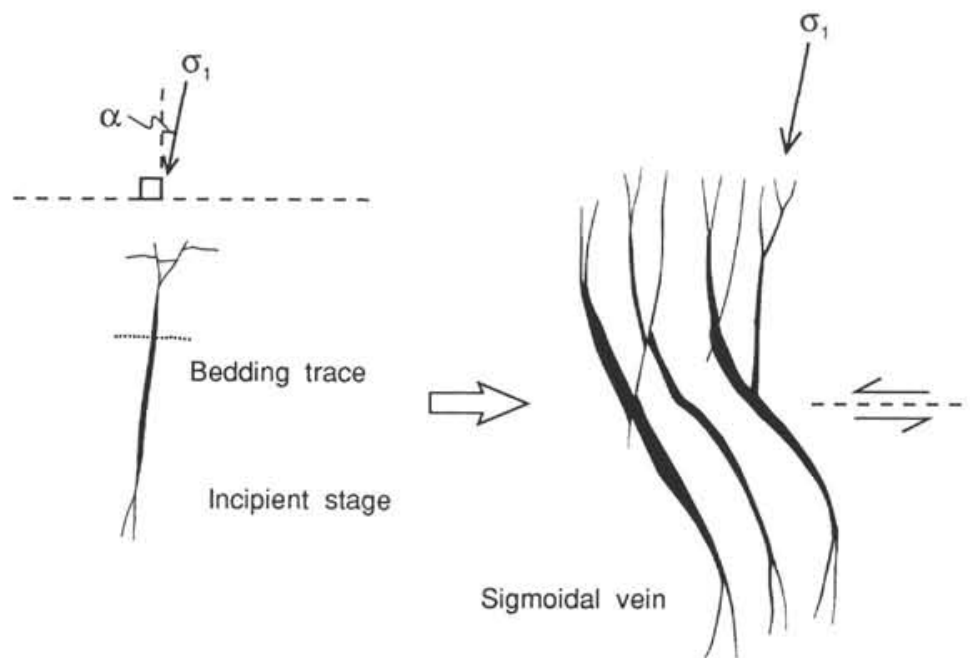

Figure 10. The incipient stage of vein, indicating a fish style (left), and the developed stage, indicating a sigmoidal style (right). $\sigma_{1}$ and $\alpha$ are discussed in Figure 13.

\section{ATTITUDE OF VEIN BY MAGNETIC MEASUREMENT}

\section{Procedure}

The cores are almost vertical, so that samples in the tube have an orientation within a horizontal X-Y plane; then the arrow is almost vertical in an $X-Z$ plane (Fig. 2). However, in this case, we do not know the real north direction in an X-Y plane. Therefore, we first assumed that $X=$ magnetic north; then we measured the strike and dip of the vein plane within this coordinate. Natural remanent magnetization (NRM) was done with the Schonstedt spinner magnetometer (SSM-1A) at the Ocean Research Institute, University of Tokyo. The NRM intensities of the samples range from $7.31 \times 10^{-6}$ to $4.55 \times 10^{-4} \mathrm{emu} / \mathrm{gr}$. The intensity was fairly stable after alternating-field (AF) demagnetization. We used a Schonstedt two-axis tumbler demagnetizer with a maximum $\mathrm{AF}$ up to 100 or $600 \mathrm{mT}$ until the sample showed a constant direction of magnetic orientation. An example of the demagnetization path is shown in Figure 11.

\section{Results}

The results of the above experiments are given in Table 1, and the attitude of each vein (calculated using the constant direction demagnetization) is projected in Figure 12. The processes may contain systematic errors that arose during the various stages. The greatest error was from the measurement of the vein plane at the beginning relative to the $\mathrm{X}$-Y plane, because most of the veins were anastomosing in two dominant directions. In all cases, we measured the general direction of the veins, so this may account for an error of about $5^{\circ}$ in the strike and dip. In addition, too few samples were measured. We usually need at least three samples from each location; however, because of the sampling policy, we were limited to one sample per core.

If we look at Figure 12, we can see that the strikes of the vein vary from $275^{\circ}$ to $360^{\circ}$ (i.e., $315^{\circ} \pm 40^{\circ}$ ), and the dips are very steep (more than $70^{\circ}$ ). Furthermore, most are vertical at Site 793 . The strong NRM measurements were taken at either the point of sedimentation or veining. The sedimentary magnetism was possibly converted at the time of the clay mineral recrystallization, or it remained still

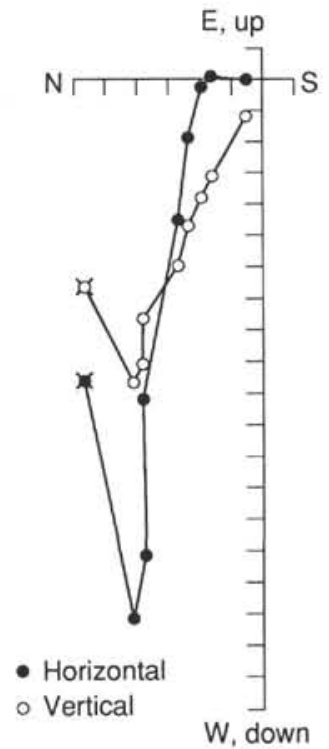

Figure 11. Example of change of orthogonal components of magnetization with AF demagnetization, Sample 126-793B-19R-2, 25-27 cm; 0-40 mT; scale = $10 \mathrm{~mA} / \mathrm{m}$ per division.

Table 1. Remanence properties of discrete samples, Holes 787B and 793B.

\begin{tabular}{|c|c|c|c|c|c|}
\hline $\begin{array}{l}\text { Core, section, } \\
\text { interval }(\mathrm{cm})\end{array}$ & $\underset{(\mathrm{mT})}{\text { Optimum AF }}$ & $\begin{array}{l}\text { Declination } \\
\text { (degrees) }\end{array}$ & $\begin{array}{l}\text { Inclination } \\
\text { (degrees) }\end{array}$ & $\begin{array}{c}J 0 \\
(\mathrm{~mA} / \mathrm{m})\end{array}$ & $\begin{array}{c}J \mathrm{AF} \\
(\mathrm{mA} / \mathrm{m})\end{array}$ \\
\hline \multicolumn{6}{|l|}{$126-787 \mathrm{~B}-$} \\
\hline $8 \mathrm{R}-1,11-13$ & 40.0 & 110.7 & 43.3 & 316.80 & 29.75 \\
\hline $9 \mathrm{R}-1,11-13$ & 10.0 & 106.9 & 55.6 & 482.40 & 67.97 \\
\hline $10 R-1,11-13$ & 20.0 & 101.8 & 19.0 & 115.20 & 18.75 \\
\hline$i 1 R-1,2 i-23$ & 7.5 & -89.4 & -65.0 & 205.20 & 66.18 \\
\hline \multirow{2}{*}{\multicolumn{6}{|c|}{$126-793 \mathrm{~B}-$}} \\
\hline $12 \mathrm{R}-1,21-23$ & & & -35.9 & 265.32 & 31.55 \\
\hline 16R-5,94-96 & 10.0 & 92.2 & 58.6 & 33.12 & 4.75 \\
\hline $17 R-2,73-75$ & 7.5 & 243.9 & -28.1 & 145.26 & 23.06 \\
\hline $18 R-3,82-84$ & 15.0 & 123.1 & 26.4 & 12.83 & 9.60 \\
\hline $19 R-4,25-27$ & 40.0 & 11.6 & -60.6 & 127.98 & 11.97 \\
\hline
\end{tabular}




\section{Hole 787B}

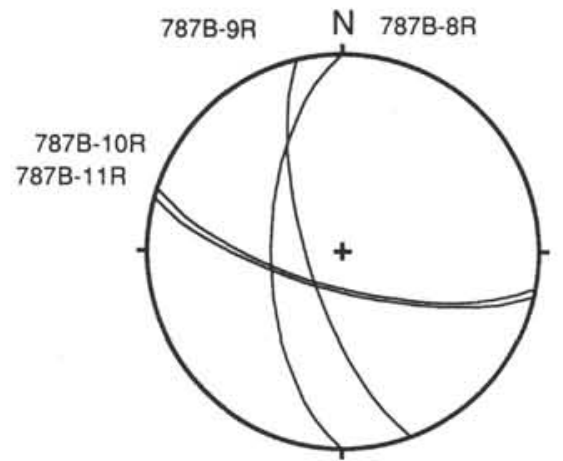

\section{Hole 793B}

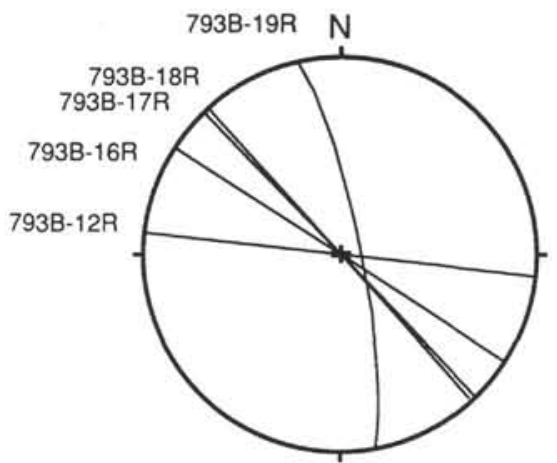

Figure 12. Calculated and projected direction of the vein plane, for the strongest NRM stage, using the Wulf's net, lower hemisphere. For sample numbers, refer to Figure 3.

strong until this time. This needs to be checked in the future. However, our tentative results imply that the veins formed with a dominantly northwest-southeast strike and subvertical dips.

\section{DISCUSSION}

\section{Tectonic Significance of Vein Structure Formation}

These kinds of vein structure were first described on land as fracture cleavages at the time of dewatering, called "beardlike veinlet structure" by Ogawa (1980) in the Miura and Boso peninsulas to the northern extension of the Izu-Bonin forearc in central Honshu. He noticed that the vein structures were associated with normal faulting under horizontally extensional conditions and acted as a dewatering path. From the sea bottom, similar structures were found from the Japan Trench landward slope by Arthur et al. (1980) and later Leggett et al. (1987); they concluded that this was a dewatering phenomena. However, most of the veins are constrained within a zone so that they form an array within a single bed. Each vein thins out to both sides, suggesting that it was not formed by dehydration. A dewatering vein that serves as a pipe or that dewaters along a fault plane differs from these vein structures. We think that the vein structures in these samples were not effectively dewatering.

Vein structures from the landward-slope sediments of the Middle America Trench have been extensively described by Cowan (1982) and Ogawa and Miyata (1985). They concluded that these vein structures were formed as fracture cleavages under horizontal extension and were later modified into sigmoidal shapes by downslope sliding. On the other hand, Helm and Vollbrecht (1985) hypothesized that these same sites were formed by antithetic Riedel shearing.

Vein structures seen within the Oceanic Formation of Barbados Island occur in the forearc basin. Also, they were found in both the seaward and landward slopes of the accretionary margin in the Barbados Ridge accretionary prism in ODPLeg 110 (Moore, Mascle, et al., 1989). In the latter case, the veins were thought to be formed by horizontal shearing around the incipient decollement zone before being incorporated into the accretionary prism (Behrmann et al., 1988; Brown and Behrmann, 1990). However, Ogawa's preliminary hypothesis during Leg 110 was that the veins were formed by vertical compression around the normal fault in the downgoing slab in an oceanic plate realm.

Kimura et al. (1989) discovered a vein structure from the piston core taken from the seaward slope of the Yap Trench and concluded that it was formed by Riedel shearing in conjunction with subhorizontal shearing planes. They thought that the vein structures needed slope instability to form a sliding plane and that the shearing associated with such a sliding regime would cause the vein structures to be Riedel or anti-Riedel shear planes.
Beside these forearc settings, the occurrence of vein structures in the backarc settings have also been reported significantly. Iwamatsu (1979) included a picture of a vein structure in the Pliocene Nishiyama Mudstone Formation on the Japan Sea side, central Honshu, that corresponds to a backarc setting. Some siliceous deposits from the Miocene Onnagawa Formation in the backarc area of the northern Honshu also yielded vein structures (T. Tsuji, pers. comm., 1990).

Thus, several tectonic settings exist for the formation of vein structures in the world. Generally, however, it can be stated that vein structures were formed on trench-landward-slope settings, with some exceptions that formed in the lower position of the incipient subduction zone decollement, as has been thought in the Barbados case and the backarc setting in central and northern Honshu. All of these settings favor a horizontal stretching of the strain field rather than a shortening of it.

Similar ideas about shear stress conditions on slopes have been suggested by such authors as Ritger (1985), Knipe (1986), Shipboard Scientific Party (1990), Saito and Nagahama (1989), and Brown and Behrmann (1990). Most of these authors have suggested that the subhorizontal shear plane may rotate around the original tension gash that developed from an extensional fracture or from a Riedel shear to a sigmoidal pattern. Sometimes these authors have claimed that the subhorizontal shear planes have penetrated the central vein structure parts as a result of strong shearing.

\section{Formation of Vein Structures}

Clay mineral formation within the veins is thought to occur as follows: The veins may originally form as either extension or shear fractures. With regard to extension fractures, they can be formed by hydraulic fracturing under high pore pressures. Even if differential stresses are not large, fluid pressures can be high enough to cause the Mohr's circle to contact the Mohr envelope surface in the diagram (Fig. 13) and extensional fractures can occur. If the differential stresses are small enough, $\Delta \sigma<4 \mathrm{~T}_{0}\left(\mathrm{~T}_{0}=\right.$ extensional strength) (Suppe, 1985). On the other hand, a conjugate shear fracture would be formed if $\Delta \sigma<-4 \sqrt{2} T_{0}$, as indicated by Suppe (1985). A hydraulic fracture can occur in nature when high pore pressure results from either tectonic pumping (Price, 1978; Moore, 1989) or compaction, which may prevent water escaping through low or no permeability. The latter case may preferentially occur when a lot of clayey sediments are present. When high pore pressure conditions continue during fracturing within the vein, the veining formation may be the last structure to develop.

When fluid pressures are equal to lithostatic pressures, parallel bedding slides may be caused even by low oblique tangential stresses on the bedding plane because that part is weak enough. In this case, the vein could be still subvertical to the bedding plane. Thus, these 


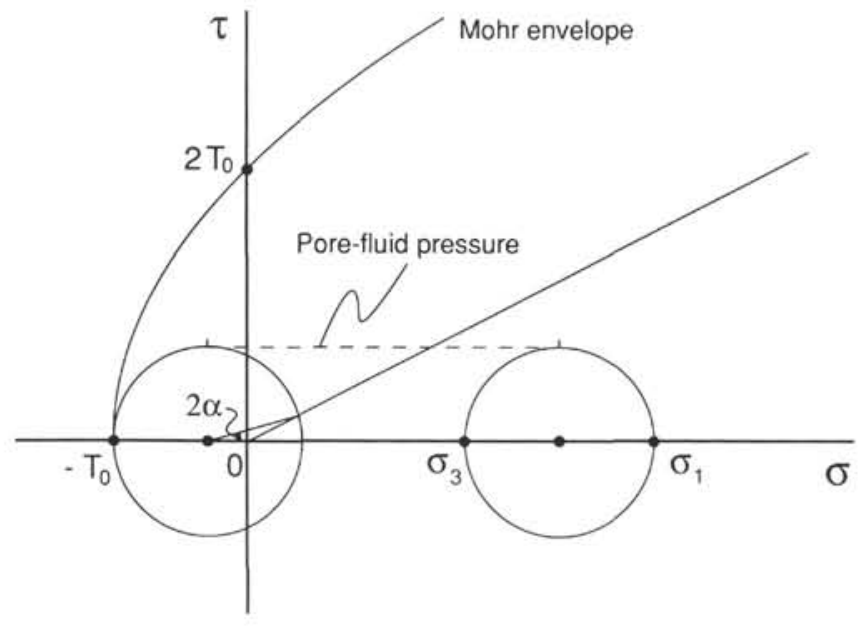

Figure 13. Simple representation of vein formation at the time of pore fluid increasing to produce hydraulic fracturing, and slip along a plane, whose normal is at an angle $\alpha$ to the $\sigma_{1}$ direction. Diagonal line is the failure line for collapsed sediment. See Figure 10.

two planes - the subvertical vein and the bedding parallel slip - can be explained by the same stress field, as discussed by Mount and Suppe (1987) and Byrne and Fisher (1990). This case is illustrated in Figure 13.

When the stress drop occurs at the time of fracturing, the surrounding pore fluids, which might be rich in suspended clay contents, invade the vein, and then clay minerals such as montmorillonite are deposited. These clay minerals are sometimes arranged parallel to the vein and sometimes at random. In the former case, this is because flow along the vein may have brought the clay grains.

At Site 784 (Leg 125), vein structures are present even in the Pliocene section. The cored samples are very soft and are called "clay" instead of claystone. This means that the veining might have occurred when the sediment became just barely compacted and were only slightly strengthened. The clay is coherent because of its clay mineral coherency; more radiolarian or vitric ash content could possibly be more rapidly cemented by the recrystallization of those materials. The fracturing needs a certain strength, either extensional or shear, before it can flow. This is one of the reasons that a definite lithology and horizon contain the vein structures.

It is known that veins are sometimes formed vertical to the bedding plane and have symmetrical braided tails on each of the edges. Usually no displacement occurs in the central part, although some displacement in a normal fault sense is seen in the braided parts. This suggests that veins originated as extension fractures from the central part and then became shear fractures at the edges, both associated with the vertical plane. On the other hand, sometimes veins are either slightly or considerably inclined to the bedding plane, which suggests that they are the result of subvertical or inclined fractures. Sometimes a slight dislocation is observed, suggesting that shear motion occurred along the vein plane. In this case, the vein originated from a normal fault (or possibly an extensional or shear joint at first) and was dislocated later in association with anastomosation and rotation. The sigmoidal vein shapes indicate that rotation is necessary during their development. The shearing sense for the bedding slip can coexist with the development of veins as a tension gash.

Thus, although there are two types of vein structures, it is notable that veins can occur as either tension gashes or shear fractures. In both cases, they usually must be vertical or subvertical to the bedding plane. The differential stress must be very small under fairly shallow depths. Several stages of vein formation are explained by the rotation of veins caused by shearing. In most cases, the sense of shear is downslope for normal faulting as it is for the vein array, as indicated in many places (Ogawa and Miyata, 1985; Shipboard Scientific Party, 1990). This strongly supports the fact that a horizontal stretching stress field occurs in the near-surface of most forearc regions.

As described in the thin section chapter, the materials within the veins are mostly clay minerals. This indicates that they were deposited in the fluid filling the vein. As discussed in Ogawa and Miyata (1985) and suggested in Shipboard Scientific Party (1990) and Knipe (1986), the stress drop (reduced stress) at the time of fracture formation might evacuate the surrounding water, which is rich in clay content, to precipitate the clay mineral. Such a hypothesis for vein formation is most preferable.

\section{Tectonic Implication of Vein Structures}

The on-land example in the Miura-Boso peninsulas was taken from the Miocene to Pliocene accretionary prism in central Honshu (Ogawa et al., 1985, 1989). In this case, the accreted sediments were thought to be deposited originally on the trench landward slope of the Izu-Bonin island arc and then incorporated landward by the subduction and accretion of the Philippine Sea Plate.

The two sites for the vein structures covered in this study are located in the outer part of the forearc basin of the Izu-Bonin island arc. This basin originated from the "failed rift" that opened along the volcanic front during the early Oligocene for a short period (Taylor, Fujioka, et al., 1990, pp. 315-403). Sediments were deposited first as volcaniclastic rocks during the Oligocene; scarce volcanic materials were then deposited during the Miocene. North-trending normal faulting occurred within the forearc basin to stretch the sediments; it is not yet known exactly when the stretching occurred in the forearc basin.

Even if the veins were formed as extensional fractures subvertical to the bedding plane or as shear tension gashes under shear stress, our results (i.e., that most vein planes trend northwest) substantiate our interpretation that the veins were formed under the northeast-stretching stress field. The veins may have formed at an early stage after sedimentation, possibly during late Oligocene to Miocene time. It is said that the Izu-Bonin island arc was once connected to the present Kyushu-Palau Ridge to form a proto Izu-Bonin-Mariana island arc before the opening of the Shikoku-Parece Vela basin (before $30 \mathrm{Ma}$; i.e., late Oligocene). We do not know the exact stage of the vein formation, but it may have occurred when the Izu-Bonin Arc was still trending northwest, or during the change from a northwest to a north trend between 30 and 16 or $12 \mathrm{Ma}$ (Seno and Maruyama, 1984; Chamot-Rooke et al., 1987; Jolivet et al., 1989). This interpretation must still be checked by various points of view, but if correct, then the veins formed during extension are perpendicular to the arc.

\section{ACKNOWLEDGMENTS}

We are grateful to the onboard staff who took the vein samples. Critical reviews and suggestions by Brian Taylor, Darrel S. Cowan, Gaku Kimura, and an anonymous reviewer are greatly appreciated. A part of the study was supported by the funds from the Cooperative Program (No. 90011) provided by the Ocean Research Institute, University of Tokyo, to Y. Ogawa.

\section{REFERENCES}

Arthur, M. A., Carson, B., and von Huene, R., 1980. Initial tectonic deformation of hemipelagic sediment at the leading edge of the Japan convergent margin. In Langseth, M., Okada, H., et al., Init. Repts. DSDP, 56, 57, Pt. 1: Washington (U.S. Govt. Printing Office), 569-613.

Behrmann, J., Brown, K., Moore, J. C., Mascle, A., Taylor, E., Alvarez, F., Andreieff, P., Barnes, R., Beck, C., Blanc, G., Clark, M., Dolan, J. F., Fisher, A., Gieskes, J., Hounslow, M. W., McLellan, P., Moran, K., Ogawa, Y., Sakai, T., Schoonmaker, J., Vrolijk, P., Wilkens, R. H., Williams, C. F., 1988. Evolution of structures and fabrics in the Barbados Accretionary Prism: insights from Leg 110 of the Ocean Drilling Program. J. Struct. Geol., 10:577-591. 
Brown, K. M., and Behrmann, J., 1990. Genesis and evolution of small-scale structures in the toe of the Barbados Ridge accretionary wedge. In Moore, J. C., Mascle, A., et al,, Proc. ODP, Sci. Results, 110: College Station, TX (Ocean Drilling Program), 229-244.

Byrne, T., and Fisher, D., 1990. Evidence for a weak and overpressured decollement beneath sediment-dominated accretionary prisms. J. Geophys. Res., 95:9081-9097.

Chamot-Rooke, N., Renard, V., and Le Pichon, X., 1987. Magnetic anomalies in the Shikoku basin: a new interpretation. Earth Planet. Sci. Lett., 83:214-228.

Cowan, D. S., 1982. Origin of "Vein Structure" in slope sediments on the inner slope of the Middle America Trench off Guatemala. In Aubouin, J., von Huene, R., et al., Init. Repts. DSDP, 67: Washington (U.S. Govt. Printing Office), 645-650.

Helm, R., and Vollbrecht, A., 1985. Brittle-ductile shear zones in slope sediments off Guatemala, Site 568 and 569, Deep Sea Drilling Project Leg 84. In von Huene, R., Aubouin, J., et al., Init. Repts. DSDP, 84: Washington (U.S. Govt. Printing Office), 625-632.

Iwamatsu, A., 1979. Cleavages in rock. In Uemura, T. (Ed.), Geologic Structures and Their Developments: Tokyo (Iwanami Book Co.), 161-185.

Jolivet, L., Huchon, P., and Rangin, C., 1989. Tectonic setting of Western Pacific marginal basins. Tectonophysics, 160:23-47.

Kimura, G., Koga, K., and Fujioka, F., 1989. Deformed soft sediments at the junction between the Mariana and Yap trenches. J. Struct. Geol., 11:463-472.

Knipe, R. J., 1986. Microstructural evolution of vein arrays preserved in Deep Sea Drilling Project cores from the Japan Trench, Leg 57. In Moore, J. C. (Ed.), Structural Fabrics Preserved in Deep Sea Drilling Project Cores from Forearcs. Mem. Geol. Soc. Am., 166:75-87.

Leggett, J. K., Lundberg, N., Bray, C. J., Cadet, J. P., Karig, D. E., Knipe, R. J., and von Huene, R., 1987. Extensional tectonics in the Honshu forearc, Japan: integrated results of Deep Sea Drilling Project Legs 57, 87, and reprocessed seismic reflection profiles. Spec. Publ., Geol. Soc. London, 28:593-609.

Lundberg, N., and Moore, J. C., 1986. Macroscopic structural features in Deep Sea Drilling Project cores from forearc regions. In Moore, J. C. (Ed.), Structural Fabrics Preserved in Deep Sea Drilling Project Cores from Forearcs. Mem. Geol. Soc. Am., 166:13-44.

Moore, J. C., 1989. Tectonics and hydrogeology of accretionary prisms: role of the decollement zone. J. Struct. Geol., 11:95-106.

Moore, J. C., Mascle, A., Taylor, E., Alvarez, F., Andreieff, P., Barnes, R., Beck, C., Behrmann, J., Blanc, G., Brown, K. M., Clark, M., Dolan, J. F., Fisher, A., Gieskes, J. M., Hounslow, M., McLellan, P., Moran, K., Ogawa, Y., Sakai, T., Schoonmaker, J., Vrolijk, P., Wilkens, R. H., and Williams, C., 1988. Tectonics and hydrogeology of the northern Barbados Ridge: results from Ocean Drilling Program Leg 110. Geol. Soc. Am. Bull., 100:1578-1593.
Mount, V. S., and Suppe, J., 1987. State of stress near the San Andreas fault: implications for wrench tectonics. Geology, 15:1143-1146.

Ogawa, Y., 1980. Beard-like veinlet structure as fracture cleavage in the Neogene siltstone in the Miura and Boso peninsulas, central Japan. Sci. Rep. Dept. Geol., Kyushu Univ., 13:321-327.

Ogawa, Y., Horiuchi, K., Taniguchi, H., and Naka, J., 1985. Collision of the Izu Arc with Honshu and the effects of oblique subduction in the MiuraBoso peninsulas. Tectonophysics, 119:349-379.

Ogawa, Y., and Miyata, Y., 1985. Vein structure and its deformation history in the sedimentary rocks of the Middle America Trench slope off Guatemala, Deep Sea Drilling Project Leg 84. In von Huene, R., Aubouin, J., et al., Init. Repts. DSDP, 84: Washington (U.S. Govt. Printing Office), 811-529.

Ogawa, Y., Seno, T., Akiyoshi, H., Tokuyama, H., Fujioka, K., and Taniguchi, H. 1989. Structure and development of the Sagami trough and the Boso triple junction. Tectonophysics, 160:135-150.

Price, N. J., 1978. Permeability, hydraulic fracture and elasticity. In Fyfe, W. S. Price, N. J., and Thompson, A. B. (Eds.), Fluids in the Earth's Crust: Amsterdam (Elsevier), 253-273.

Ritger, S. D., 1985. Origin of vein structures in the slope deposits of modern accretionary prisms. Geology, 33:437-439.

Saito, S., and Nagahama, H., 1989. Geometry and geological significance of "vein structure" in soft sediment. J. Tecton. Res. Group Jpn., 34:27-36.

Seno, T., and Maruyama, S., 1984. Paleogeographic reconstruction and origin of the Philippine Sea. Tectonophysics, 102:53-84.

Shipboard Scientific Party, 1990. Site 784. In Fryer, P., Pearce, J. A., et al., Proc, ODP, Init. Repts., 125: College Station, TX (Ocean Drilling Program), 273-305.

Suppe, J., 1985. Principles of Structural Geology. Englewood Cliffs, NJ (Prentice-Hall).

Taylor, B., Fujioka, K., et al., 1990. Proc. ODP, Init. Repts., 126: College Station, TX (Ocean Drilling Program).

Taylor, B., Moore, G., Klaus, A., Systrom, M., Cooper, P., and MacKay, M., 1990. Multichannel seismic survey of the central Izu-Bonin Arc. In Taylor, B., Fujioka, K., et al., Proc. ODP, Init. Repts., 126: College Station, TX (Ocean Drilling Program), 51-60.

Date of initial receipt: 2 November 1990

Date of acceptance: 29 May 1991

Ms 126B-128 